\title{
Kierunki reformy arbitrażu inwestycyjnego w ramach prac Grupy Roboczej III UNCITRAL
}

\begin{abstract}
The goal of the study is to briefly present the work on the reform of investment arbitration under the auspices of the United Nations Commission on International Trade Law (UNCITRAL) and to indicate the directions in which further discussion on this reform could potentially go. The Commission entrusted to Working Group III to work on the reform of international investment dispute resolution mechanisms. The ongoing debate in this area has met with very little interest in Polish literature. It is surprising since its outcome may have an impact on future investment policy also in Poland. The work is divided into five parts. The first part presents the scope of the work and the research methodology. The second one presents a very concise historical background for the establishment of investment arbitration, taking into account the key features underlying current crisis of this institution. The third part briefly outlines the course of work of UNCITRAL Working Group III. This section provides a background to show how negotiations are progressing, what major obstacles negotiators are facing and what the future direction of the Working Group's work might be. These issues are discussed in the fourth part of the study. Author's opinion on anticipated development of further discussion is presented in the closing remarks.
\end{abstract}

Keywords: investment arbitration reform, investment arbitration crisis, rule of law, UNCITRAL Working Group III, ICSID

a) Dr hab., Uniwersytet Ślaski w Katowicach. 


\section{Uwagi wprowadzające}

Celem niniejszego opracowania jest zwięzłe przedstawienie prac nad reformą arbitrażu inwestycyjnego, które toczą się pod auspicjami Komisji Narodów Zjednoczonych ds. Międzynarodowego Prawa Handlowego (UNCITRAL), oraz wskazanie, w jakich kierunkach może potencjalnie zmierzać dalsza dyskusja dotycząca tej reformy. Komisja w toku 50. sesji, jaka odbywała się w lipcu 2017 r., powierzyła Grupie Roboczej III (Working Group III) prace nad reformą międzynarodowych mechanizmów rozstrzygania sporów inwestycyjnych ${ }^{1}$. Tocząca się $\mathrm{w}$ tym zakresie debata spotyka się z zaskakująco niewielkim zainteresowaniem w krajowej literaturze ${ }^{2}$, choć jej wynik może rzutować na kształt przyszłej polityki in-

${ }^{1}$ Report A/72/17, §240-265, s. 43-47.

${ }^{2}$ Prace Grupy Roboczej relacjonowane są na bieżąco na blogu Przegląd Prawa Międzynarodowego. Ostatni wpis dotyczący tej tematyki można znaleźć pod adresem http://przegladpm.blogspot.com/2020/02/reforma-uncitral-arbitrazu.html. Serię publikacji przedstawiających słabości arbitrażu inwestycyjnego przedstawił Ł. Kułaga; zob. Ł. Kułaga: Międzynarodowy arbitraż inwestycyjny z perspektywy zasady rzqdów prawa. W: Arbitraż $w$ prawie międzynarodowym. Red. C. Mik. Warszawa, C.H. Beck, 2014, s. 202-220; Idem: Ochrona praw człowieka $w$ międzynarodowym arbitrażu inwestycyjnym. „Forum Prawnicze” 2014, nr 1, s. 41-59; Id e m: Międzynarodowa ochrona środowiska a swoboda handlu. W: Swoboda handlu międzynarodowego w prawie międzynarodowym. Red. C. Mik, M. Jeżewski. Warszawa 2014, s. 301-331; Idem: W kierunku zmiany paradygmatu międzynarodowych porozumień inwestycyjnych. „Forum Prawnicze" 2016, 5 (37), s. 31-48; Idem: Prawo państwa do regulacji a międzynarodowe prawo inwestycyjne: $w$ kierunku zmiany paradygmatu. „Problemy Współczesnego Prawa Międzynarodowego, Europejskiego i Porównawczego" 2019, T. 17, s. 11—32, z tym że prace te nie odnoszą się do prowadzonej debaty w ramach Grupy Roboczej UNCITRAL. Uwadze czytelnika polecić można także wiele innych pozycji krajowych poświęconych różnym zagadnieniom z zakresu arbitrażu inwestycyjnego. Z nowszych, obszerniejszych opracowań zob. M. Jeżewski: Międzynarodowe prawo inwestycyjne. Warszawa 2019; M. Kałduński: Ochrona uzasadnionych oczekiwań $w$ międzynarodowym prawie inwestycyjnym. Torun 2019; M. Pyka: Pojęcie inwestycji $w$ międzynarodowym arbitrażu inwestycyjnym. Warszawa 2018; K. Czech: Dowody i postępowanie dowodowe $w$ międzynarodowym arbitrażu handlowym oraz inwestycyjnym. Zagadnienia wybrane. Warszawa 2017. W pozostałym zakresie zob. m.in.: J. Rajski: Zagadnienia poufności $i$ transparentności $w$ międzynarodowym arbitrażu kontraktowym (handlowym) $i$ traktatowym (inwestycyjnym). W: „Aurea praxis, aurea theoria”. Ksiega pamiatkowa ku czci Profesora Tadeusza Erecińskiego. T. 2. Red. J. Gudowski, K. Weitz. Warszawa 2011; S. Sołtysiński: Arbitraż inwestycyjny, kohabitacja z wymiarem sprawiedliwości, rosnace koszty $i$ inne problemy sqdownictwa polubownego. W: „Aurea praxis, aurea theoria”. Księga pamiqtkowa ku czci Profesora Tadeusza Erecińskiego. T. 2. Red. J. Gudowski, K. Weitz...; A. Szumański: Poufność czy jawność arbitrażu handlowego oraz inwestycyjnego. W: Państwo prawa i prawo karne. Księga jubileuszowa Profesora Andrzeja Zolla. T. 1. Red. P. Kardas, T. Sroka, W. Wróbel. Warszawa 2012; G. Domański, 
westycyjnej także w Polsce. W tym kontekście zadziwia również bierność Polski jako uczestnika dyskusji na forum Grupy Roboczej. Obrany w kraju kierunek polityczny, polegajacy na wypowiadaniu bądź rozwiązywaniu wiążących Polskę umów inwestycyjnych, nie odetnie bowiem Polski od potrzeby zaadaptowania się w przyszłości do globalnych rozwiązań inwestycyjnych. Niniejsza publikacja nie aspiruje do tego, aby w pełni zdiagnozować kondycję arbitrażu inwestycyjnego, powinna natomiast stanowić zachętę do podjęcia głębszej dyskusji nad kierunkami rozwoju ochrony międzynarodowych inwestycji oraz nad zaangażowaniem Polski w tym zakresie na forum międzynarodowym.

Zanim podjęte zostaną rozważania dotyczące reformy arbitrażu inwestycyjnego, warto zwrócić uwagę na określenie jej przedmiotu i zdefiniowanie tej kategorii pojęciowej. Nie ulega wątpliwości, że arbitraż inwestycyjny jest instrumentem ochrony inwestora zagranicznego przed działaniami państwa zlokalizowania inwestycji ${ }^{3}$. Spór rozstrzyga insty-

J. Zimoch-Tuchołka: Atrybucja $w$ międzynarodowym arbitrażu inwestycyjnym. W: Arbitraż i mediacja. Księga jubileuszowa dedykowana doktorowi Andrzejowi Tynelowi. Red. M. Łaszczuk, M. Furtek, S. Pieckowski, J. Poczobut, M. Tomaszewski, A. Szumański. Warszawa 2012; M. Świątkowski: Czy wyrok sqdu stanowi „inwestycje” $w$ rozumieniu traktatów o ochronie inwestycji? W: Arbitraż $i$ mediacja. Księga jubileuszowa dedykowana doktorowi Andrzejowi Tynelowi. Red. M. Łaszczuk, M. Furtek, S. Pieckowski, J. Poczobut, M. Tomaszewski, A. Szumański...; E.H. Morawska: Zagadnienia praw człowieka $w$ międzynarodowym arbitrażu inwestycyjnym. W: Arbitraż w prawie międzynarodowym. Red. C. Mik. Warszawa 2014; M. Jeżewski: How Wide is the Door to Turn Contracts into Treaty Obligations? Reflections on Prof. Rajski's Dissenting Opinion in Eureko. In: The Challenges and The Future of Commercial and Investment Arbitration. Liber Amicorum Professor Jerzy Rajski. Ed. B. Gessel Kalinowska vel Kalisz. Warszawa 2015; K. Michałowska: Some Manifestations of Public Interest in Investment Arbitration. In: The Challenges and The Future of Commercial and Investment Arbitration. Liber Amicorum Professor Jerzy Rajski. Ed. B. Gessel Kalinowska vel Kalisz...; C. Mik: Unia Europejska wobec międzynarodowego prawa inwestycyjnego. W: „Iura et Negotia”. Księga jubileuszowa z okazji 15-lecia Wydziatu Prawa i Administracji Uniwersytetu Kardynata Stefana Wyszyńskiego. Red. A. Tarwacka. Warszawa 2015; M. Muszyński: Inwestycje zagraniczne $w$ prawie międzynarodowym. W: „Iura et Negotia”. Księga jubileuszowa z okazji 15-lecia Wydziału Prawa i Administracji Uniwersytetu Kardynata Stefana Wyszyńskiego. Red. A. Tarwacka...; K. Wierzbowski: Konflikt pomiędzy rozstrzygnięciami sqdów arbitrażowych w sprawach z umów BIT a prawem wspólnotowym w świetle wybranego orzecznictwa trybunałów arbitrażowych i Komisji Europejskiej. W: „Usus magister est Optimus”. Rozprawy prawnicze ofiarowane Profesorowi Andrzejowi Kubasowi. Red. B. Jelonek-Jarco, R. Kos, J. Zawadzka. Warszawa 2016.

${ }^{3}$ Ze względu na ograniczony zakres publikacji nie zajmuję się problematyką tego, co można uznać za inwestycję i w jakich przypadkach inwestycja ma charakter inwestycji zagranicznej. W uproszczeniu stwierdzić można, że w znacznej mierze o tym, czy konkretne działania danego podmiotu wyczerpują podmiotowe i przedmiotowe przesłanki inwestycji zagranicznej, decydują in concreto przepisy właściwe dla danego sporu. 
tucja zewnętrzna w stosunku do państwa, a stronami są zawsze inwestor i państwo. W obecnych ramach prawnych strony sporu mają bezpośredni wpływ na wybór składu orzekajacego. Poza wymienionymi cechami, trudno jest wskazać na inne, które będą wspólne wszystkim sporom inwestycyjnym. Podstawą prawną większości postępowań inwestycyjnych sa umowy dwustronne między państwami (tzw. umowy BIT), których zawarto ponad 3 tys. ${ }^{4} \mathrm{~W}$ ostatnim czasie zwiększa się znaczenie wielostronnych umów o wymianie handlowej $\left(\mathrm{NAFTA}^{5} / \mathrm{USMCA}^{6}, \mathrm{RCEP}^{7}\right.$ czy też umowy zawierane ostatnio między Unią Europejską a jej partnerami handlowymi). Nie można również pomijać umów zawieranych bezpośrednio między państwami a inwestorami, które także stanowią podstawę ewentualnych sporów inwestycyjnych, jednak ich skala jest zdecydowanie mniejsza niż skala umów zawieranych między państwami ${ }^{8}$. Ostatecznie więc $\mathrm{w}$ sprawach $\mathrm{z}$ zakresu arbitrażu inwestycyjnego istnieja różne podstawy materialnoprawne rozstrzygnięcia. Obraz komplikuje dodatkowo fakt, że postępowania toczą się na podstawie różnych procedur, co oznacza, że postępowania inwestycyjne nie mają także wspólnej wszystkim sporom podstawy proceduralnej ${ }^{9}$. Dominuja jednak postępowania prowadzone na podstawie reguł $\operatorname{ICSID}^{10}$. Niektórzy autorzy twierdzą, że trudno jest w zakresie arbitrażu inwestycyjnego zidentyfikować istnienie jakichś multilateralnych powiązań tworzących ponadnarodowy

${ }^{4}$ Report of the United Nations Commission on International Trade Law, 50th session, A/72/17 § 244, s. 43 [dalej: Report A/72/17], https://undocs.org/en/A/72/17.

${ }^{5}$ North American Free Trade Agreement - północnoamerykańskie porozumienie handlowe z 1992 r., zob. więcej: https://www.cbp.gov/trade/nafta.

${ }^{6}$ USMCA (United States-Mexico-Canada Agreement) jest porozumieniem, które ma zastąić porozumienie NAFTA, zob. więcej: https://ustr.gov/usmca.

${ }^{7}$ The Regional Comprehensive Economic Partnership - porozumienie handlowe państw z obszaru Azji i Pacyfiku, zob. więcej: https://www.business-standard.com/about/ what-is-rcep.

${ }^{8}$ J. Bonnitcha: Assessing the Impacts of Investment Treaties: Overview of the evidence. International Insttitute for Sustainable Development (IISD) Report, September 2017, s. 1, https://www.iisd.org/sites/default/files/publications/assessing-impacts-inve stment-treaties.pdf.

${ }^{9}$ X. Carim: International Investment Agreements and Africa's Structural Transformation: A Perspective from South Africa. In: Rethinking Bilateral Investment Treaties: Critical Issues and Policy Choices. Eds. K. Singh, B. Ilge. Amsterdam-New Delphi 2016, s. 54, https://www.somo.nl/wp-content/uploads/2016/03/Rethinking-bilateral-in vestment-treaties.pdf.

${ }^{10}$ T. Schultz, C. Dupont (Investment Arbitration: Promoting the Rule of Law Or Over-Empovering Investors? A Quantitative Empirical Study. „The European Journal of International Law" 2015, vol. 25, no. 4, s. 1150, http://www.ejil.org/pdfs/25/4/2551.pdf) wskazują rozłożenie procentowe badanych spraw, z przewaga spraw rozpatrywanych na podstawie umów BIT (jeśli chodzi o podstawy materialnoprawne) oraz spraw rozstrzyganych w ramach procedury ICSID (jeśli chodzi o podstawy procesowe). 
system prawny ${ }^{11}$. Jednocześnie można wskazać na wspólne całemu systemowi trendy i tendencje, dlatego też inni autorzy uważaja, że doszło do stworzenia sieci umów inwestycyjnych, a oparte na nich orzeczenia arbitrażowe wykształciły jednorodne, zwyczajowe prawo inwestycyjne ${ }^{12}$.

Przed podjęciem dalszych rozważań trzeba więc zaznaczyć, że jakiekolwiek wnioski ogólne dotyczące arbitrażu inwestycyjnego obarczone sa nieusuwalna skaza. Z jednej strony oceniana jest kondycja całego arbitrażu inwestycyjnego i wysuwane sa postulaty uniwersalne, z drugiej strony zaś każda sprawa arbitrażowa jest indywidualna i opiera się na właściwej tylko jej podstawie prawnej ${ }^{13}$. Dodatkowym problemem jest ograniczony dostęp do danych dotyczących zarówno przebiegu spraw arbitrażowych, jak i informacji nieodnoszacych się bezpośrednio do samego postępowania, ale stanowiących tło konkretnego sporu ${ }^{14}$. Nawet najszersze badania arbitrażu inwestycyjnego nie mają więc wiarygodności statystycznej i sami ich autorzy podkreślaja, że uzyskany obraz jest fragmentaryczny i może jedynie wzmocnić lub osłabić intuicyjne przekonania badaczy $^{15}$.

${ }^{11}$ S. Djajić: Searching for purpose: Critical assessment of teleological interpretation of treaties in investment arbitration. „International Review of Law”, Issue 3 - Special issue of International Investment Treaties, 2016, s. 8, https://journals.qu.edu.qa/index. php/IRL/article/view/1217/658.

${ }_{12}$ Tak sugeruje S. Schwebel: The Influance of Bilateral Investment Treaties on Customary International Law. In: Proceedings 98 ${ }^{\text {th }}$ Annual Meeting of the American Society of International Law 2004, 27 (za: S. Djajić: Searching..., s. 8).

${ }_{13}$ Zwraca na to uwagę S. Djajić: Searching..., s. 3. Nie można, oczywiście, zapominać, że wiele umów bilateralnych zawiera zbliżone do siebie rozwiązania i często opieraja się one na umowach wzorcowych konkretnych państw, co w pewnym stopniu upodabnia stany prawne będące podstawą rozstrzygnięć.

${ }_{14}$ Zwracają na to uwagę T. Schultz, C. Dupont: Investment Arbitration..., s. 1150. W konsekwencji różni autorzy, przedstawiając własne stanowiska, ograniczają się do prezentacji poszczególnych orzeczeń, które albo są popierane, albo krytykowane. Tak np. W. Sadow ski (Protection of the Rule of Law in the European Union Through Investment Treaty Arbitration: Is Judicial Monopolism the Right Response to Illiberal Tendencies in Europe? „Common Market Law Review” 2018, 55, s. 1034), gdy na podstawie kazusu Saluka i kilku innych formułuje wniosek, że arbitraż inwestycyjny nie stwarza realnego zagrożenia dla samostanowienia państw. Na tej podstawie wysuwa tezę, że kryzys arbitrażu jest wynikiem politycznej nagonki wykreowanej językiem mainstreamowych mediów, które upraszczają obraz i generalizują pojedyncze negatywne przypadki.

Problem z dostępem do rzetelnej informacji dotyczy nie tylko przebiegu spraw arbitrażowych, czasem także ich szerszego kontekstu - jako przykład posłużyć mogą długotrwałe starania różnych podmiotów o udzielenie przez rząd Australii informacji na temat kosztów poniesionych przez ten kraj w sporze z Philip Morris.

${ }_{15}$ T. Schultz, C. Dupont: Investment Arbitration..., s. 1149. Nie oznacza to oczywiście, że takie badania nie sa prowadzone. Do ich wyników trzeba jednak zawsze podchodzić z odpowiednim dystansem. 
Biorąc pod uwagę powyższe ograniczenia badawcze, można jednak postawić tezę, że arbitraż inwestycyjny znajduje się obecnie w głębokim kryzysie. Badacze zajmujacy umiarkowane stanowisko w stosunku do tej instytucji wskazują na problemy związane z długością postępowania, jego kosztami, homogenicznością społeczności arbitrażowej (co wpływać ma na dominację określonego światopoglądu oddziałującego na ocenę stanów faktycznych), niezależnością i bezstronnością arbitrów czy wreszcie niedostateczna kontrola prawidłowości rozstrzygnięć arbitrażowych oraz rozbieżnością orzecznictwa ${ }^{16}$. Autorzy bardziej krytyczni wobec tej instytucji (wśród których usłyszeć można także głosy skrajne) uznają, że wyliczenie to, choć prawidłowe, nie jest wyczerpujace. Krytycy arbitrażu inwestycyjnego twierdza, że obecny kryzys tej instytucji ma głębsza i strukturalną naturę (co w skrajnej ocenie prowadzi do wniosku, że instytucji tej nie da się zreformować). Wskazuje się wówczas na nienależytą ochronę procesową osób, które zostaną dotknięte skutkami rozstrzygnięcia arbitrażowego, dewastujące działanie arbitrażu inwestycyjnego z perspektywy praworządności państwa goszczacego, na mrożacy wpływ arbitrażu na krajową aktywność ustawodawczą w zakresie ochrony interesu publicznego ${ }^{17}$ czy też szeroko ujmowaną asymetrię tego sposobu rozstrzygania sporów ${ }^{18}$. Dogłębną krytykę arbitrażu inwestycyjnego przeprowadził w 2007 r. Gus Van Harten ${ }^{19}$. Większość ówczesnych twierdzeń tego autora pozostaje aktualna także dzisiaj, w związku z brakiem systemowej reformy tej instytucji. Obecne wypowiedzi kwestionujące fundamenty arbitrażu inwestycyjnego stanowią w większości rozwinięcie tez wówczas postawionych.

Wywody zaprezentowane $\mathrm{w}$ niniejszym opracowaniu (poza przytoczonymi uwagami wprowadzającymi) zostały ujęte w czterech kolejnych częściach. W pierwszej zwięźle omówiono historię rozwoju arbitrażu inwestycyjnego. Przedstawienie tła historycznego jest konieczne, ponieważ pozwala wykazać źródła zjawisk, które leżą u podstaw kryzysu tej instytucji. W drugiej części zarysowano przebieg prac Grupy Roboczej III

${ }^{16}$ Na problemy istniejące na tym tle wskazują M. Lang ford, D. Behn, L. Létour neau-Tremblay: Empirical perspectives on investment arbitration: What do we know? Does it matter? In: ISDS Academic Forum Working Group 7 Paper, https://www.cids.ch/ images/Documents/Academic-Forum/7_Empirical_perspectives_-_WG7.pdf.

${ }^{17}$ G. Van Harten, J. Kelsey, D. Schneiderman: Phase 2 of the UNCITRAL ISDS Review: Why 'Other Matters' Really Matter (2019). All Papers 328, s. 3 i 4, https:// digitalcommons.osgoode.yorku.ca/cgi/viewcontent.cgi?article=1335\&context=all_papers.

18 Szerzej na ten temat w tekście A. Arcuri, F. Violi: Reforming ISDS: Changing (Almost) Everything, So That Everything Stays the Same?, September 26, 2019, https:// ssrn.com/abstract $=3459961$.

${ }_{19}$ G. Van Harten: Investment Treaty Arbitration and Public Law. Oxford University Press 2007. 
UNCITRAL do chwili złożenia niniejszej publikacji do druku. Zaprezentowanie pełnego obrazu wymagałoby oczywiście znacznie obszerniejszej relacji, poświęconej wyłącznie temu zagadnieniu (w szczególności sięgnięcia do stenogramów prac Grupy Roboczej). Ta część opracowania stanowi jedynie tło przebiegu negocjacji, a także obrazuje kluczowe przeszkody i problemy, jakie stoja przed negocjatorami. Tak zarysowany obraz pozwala na wskazanie potencjalnych dalszych kierunków prac Grupy Roboczej. Ten watek omawiany jest w trzeciej części. W zamykajacym opracowanie podsumowaniu przedstawiono opinię autora, dotycząca perspektyw dalszego rozwoju prac w ramach Grupy Roboczej.

\section{Rys historyczny}

Podstawowym celem umów inwestycyjnych jest ochrona inwestycji zagranicznych, przede wszystkim przed dyskryminacyjnymi działaniami podejmowanymi przez władze krajowe w stosunku do kapitału zagranicznego ${ }^{20}$. Jeżeli przeanalizuje się źródła i przyczyny powstania arbitrażu inwestycyjnego, tak określony cel zawierania tych umów brzmi wiarygodnie. Umowy inwestycyjne są wytworem rozwoju prawa międzynarodowego w XX w. Konieczność stworzenia nowych instrumentów ochrony zagranicznych inwestycji prywatnych była wynikiem zakończenia ery kolonialnej i kształtowania się nowego ładu na świecie po drugiej wojnie światowej ${ }^{21}$. Po zakończeniu procesu dekolonizacji na mapie świata pojawiło się wiele nowych państw, których systemy polityczne najczęściej nie zaadaptowały rozwijajacej się w tym czasie w państwach zachodnich demokracji liberalnej. Jednocześnie, mimo odzyskania niepodległości, byłe państwa kolonialne pozostały w silnych związkach gospodarczych z wcześniejszymi metropoliami. Infrastruktura gospodarcza w tych państwach stanowiła często własność przedsiębiorców, którzy

${ }^{20}$ Zob. np. J. Bonnitcha: Assessing..., s. 5. Bardziej rozbudowany opis celów systemu ochrony inwestycji prezentuja: S. Puig, G. Shaffer: Imperfect Alternatives: Institutional Choice and the Reform of Investment Law. „The American Journal of International Law" 2018, 112, s. 368 i n.

${ }^{21}$ Szerszy rys historyczny dotyczący źródeł arbitrażu inwestycyjnego przedstawia L. Rönnelid: Research Report: An Evaluation of the Proposed Multilateral Investment Court System, An independent report commissioned by the European United Left/Nordic Green Left (GUE/NGL) in the European Parliament 2018, s. 10 i n., https://www. guengl.eu/content/uploads/2019/03/MIC_vRET_web_FINAL2.pdf; zob. także S. Puig, G. Shaffer: Imperfect Alternatives..., s. 363 i n. 
wcześniej inwestowali w koloniach, a obecnie stali się przedsiębiorcami zagranicznymi. Wiele nowo powstałych państw borykało się z problemem rażącego deficytu kapitału, który stał się podstawą działań, zmierzających do wykorzystania lub przejęcia kapitału prywatnego operującego wówczas na ich terenie. Tendencje te podsycane były dodatkowo niechęcia do byłych kolonizatorów. Metropolie dążyły zatem do zawierania z byłymi koloniami umów o ochronie inwestycji, które miały zapewnić bezpieczeństwo inwestycjom istniejaccym lub dokonywanym na terytoriach nowo powstałych państw ${ }^{22}$. Instrumentem tej ochrony stał się z czasem arbitraż inwestycyjny ${ }^{23}$. Instrument ten miał zneutralizować naturalną asymetrię między nieograniczoną władzą państwa na własnym terenie a zależnymi od decyzji tej władzy podmiotami prywatny$\mathrm{mi}^{24}$. Podstawową zaletą tej instytucji miało być odpolitycznienie sporów inwestycyjnych, problemy przedsiębiorców prywatnych bowiem przestały być przedmiotem rozmów na poziomie państwowym. Rozstrzyganiem konfliktu między inwestorem i państwem zając się miały niezwiązane $\mathrm{z}$ władzą państwową trybunały arbitrażowe. Władze $\mathrm{w}$ państwie inwestora teoretycznie przestały być poddawane lobbingowi inwestorów, majacemu na celu wywarcie presji dyplomatycznej na władze drugiego państwa, w którym naruszano prawa inwestora ${ }^{25}$. Jednocześnie sporów tych nie rozstrzygały sądy krajowe, co do których bardzo często pojawiały się wątpliwości dotyczące ich bezstronności i niezależności. Tym

${ }^{22}$ T. Wälde: The Energy Charter Treaty: An East-West Gateway for Investment and Trade. Kluwer Law International 1996, s. 208, cyt. za: T. Schultz, C. Dupont: Investment Arbitration..., s. 1152. Ze względu na znaczna przewagę negocjacyjną państwa rozwinięte często praktycznie jednostronnie narzucały brzmienie umów inwestycyjnych. Zob. przykłady umów zawieranych przez państwa rozwinięte z państwami Ameryki Południowej N. Monebhurrun: Is investment arbitration an appropriate venue for environmental issues? A Latin American perspective, Revista De Direito Inernacional. „Brazilian Journal of International Law" 2013, 10, s. 199.

${ }_{23}^{23}$ D. Behn, T. Laudal Berge, M. Langford (Poor States or Poor Governance? Explaining Outcomes in Investment Treaty Arbitration. „Northwestern Journal of International Law \& Business" 2018, 38, s. 341) zwracają uwagę, że choć pierwsza umowa o ochronie inwestycji została zawarta w 1959 r., arbitraż inwestycyjny pojawił się w takich umowach prawie dekadę później.

${ }^{24}$ Zob. opinie przytaczane przez G. Van Harten: Investment Treaty Arbitration. Procedural Fairness, and the Rule of Law (tekst, który stanowi podstawę odwołań w niniejszym opracowaniu, zob. http://ssrn.com/abstract=1658523; tekst ostateczny dostępny $\mathrm{w}$ pracy International Investment Law and Comparative Public Law. Ed. S.W. Schill. Oxford 2010), s. 1.

${ }^{25}$ Zob. jednak badania powołane przez J. Bonnitcha: Assessing..., s. 7 i 8 . Znamienne jest, że przywołane badania, oparte na analizie dokumentów ujawnionych przez WikiLeaks, nie uzasadniały stwierdzenia, że dyplomacja Stanów Zjednoczonych przestała angażować się w wątki inwestycji prywatnych w ramach międzynarodowych stosunków dyplomatycznych, mimo istnienia arbitrażu inwestycyjnego. 
samym siła arbitrażu inwestycyjnego wynikała w dużym stopniu ze słabości innych rozwiązań ${ }^{26}$.

Do drugiej połowy lat dziewięćdziesiątych ubiegłego stulecia dominowały umowy zawierane pomiędzy państwami rozwiniętymi a państwami rozwijającymi się 27 . Jednocześnie statystyki spraw arbitrażowych z tego okresu obrazuja, że ochrona inwestorów przebiegała praktycznie jednokierunkowo: inwestorzy z krajów rozwiniętych pozywali kraje rozwijajace $\operatorname{sie}^{28}$. Od tego czasu sytuacja uległa diametralnej zmianie. Umowy o ochronie inwestycji zaczęły być zawierane również pomiędzy państwami rozwiniętymi, a także pojawiły się umowy wielostronne, w których uczestniczyły zarówno państwa rozwinięte, jak i rozwijające się (prekursorem tego trendu była NAFTA, wiążąca Stany Zjednoczone, Kanadę i Meksyk). W arbitrażu inwestycyjnym skutkowało to pojawieniem się spraw, w których stronami stały się również państwa rozwinięte ${ }^{29}$. Zjawisko to nie miało jednak wpływu na fakt, że nadal postępowania wszczynaja głównie inwestorzy z państw rozwiniętych ${ }^{30}$. Jednocześnie sa to w większości podmioty duże; ścieżka ta nie jest wykorzystywana przez drobnych inwestorów ${ }^{31}$. Zjawisko to dowodzi, że arbitraż inwestycyjny jest niedostępny dla mniejszych podmiotów gospodarczych. Jeśli uwzględni się, że przeciętna sprawa arbitrażowa wiąże się średnio z kosztami na poziomie $4 \mathrm{mln}$ dolarów ${ }^{32}$, to brak sporów dotyczących spraw o mniejszej wartości staje się zrozumiały. Taka skala wydatków oznacza, że arbitraż inwestycyjny nie jest instrumentem adekwatnym dla inwestycji mniej-

${ }^{26}$ G. Van Harten: Investment Treaty Arbitration..., s. 2.

27 T. Schultz, C. Dupont: Investment Arbitration..., s. 1155-1156.

28 T. Schultz, C. Dupont (Investment Arbitration..., s. 1153) odwołują się w tym zakresie do M. Sornaraja h: Toward Normlessness: The Ravage and Retreat of Neo-Liberalism in International Investment Law. „Yearbook of International Investment Law \& Policy" 2010, 2, s. 618 i n.

${ }_{29}$ T. Schultz, C. Dupont: Investment Arbitration..., s. 1156.

${ }^{30}$ Ibidem.

${ }^{31}$ Szerokie badania, dotyczące m.in. rozmiarów podmiotów pozywających w arbitrażu inwestycyjnym, przeprowadzili G. Van Harten, P. Malysheuski: Who Has Benefited Financially from Investment Treaty Arbitration? An Evaluation of the Size and Wealth of Claimants, January 11, 2016. „Osgoode Legal Studies Research Paper” 2016, no. 14, https://ssrn.com/abstract=2713876 or http://dx.doi.org/10.2139/ssrn.2713876.

${ }^{32}$ J. Bonnitcha: Assessing..., s. 14. Zob. także G. Van Harten, M.C. Porterfield, K.P. Gallagher: Investment Provisions in Trade and Investment Treaties: The Need for Reform, A Global Economic Governance Initiative Policy Brief, s. 4, https://www. bu.edu/pardeeschool/files/2014/12/Investor-State-Disputes-Policy-Brief.pdf. Na gwałtowny wzrost kosztów arbitrażu inwestycyjnego zwraca uwagę J. Cosmos: Legitimacy Crisis in Investor - State International Arbitration System: A Critique on the Suggested Solutions \& the Proposal on the Way Forward. „International Journal of Scientific and Research Publications" 2014, 4, s. 8. 
szej wartości. Jest on wówczas nieopłacalny finansowo dla inwestora bez względu na finalny wynik sprawy.

Opisany trend, polegający na tym, że w postępowaniach występuja obecnie nie tylko państwa rozwijające się, lecz również państwa rozwinięte, częściowo stanowi źródło obecnego kryzysu arbitrażu inwestycyjnego. Niektórzy autorzy twierdza, że arbitraż inwestycyjny został stworzony jako instrument rozwoju rule of law w państwach rozwijających się $^{33}$. Niezależne trybunały miały stanowić zabezpieczenie przed nieskutecznym, powolnym bądź stronniczym działaniem sądów krajowych ${ }^{34}$. Celem systemu arbitrażowego miało być przywrócenie supremacji rule of law tam, gdzie zasada ta zagrożona jest w ramach systemu sądownictwa krajowego ${ }^{35}$. To uzasadnienie aksjologiczne mogło brzmieć przekonująco wówczas, gdy stronami umów o ochronie inwestycji były z jednej strony państwa rozwinięte, a z drugiej - państwa rozwijające się, które najczęściej cechował deficyt poszanowania praworządności ${ }^{36}$. Teza o potrzebie udzielenia zewnętrznej ochrony inwestycjom zagranicznym przestała brzmieć wiarygodnie w zetknięciu z systemem prawnym państw, w których prawidłowo funkcjonują instytucje demokratyczne, a sądy sa faktycznie niezawisłe i w pełni realizują zasadę równości stron postępowania. Trudno jest wówczas wykazywać, że sądy krajowe dyskryminuja podmioty zagraniczne ${ }^{37}$. Postępowania arbitrażowe, w których występują państwa przestrzegające zasady trójpodziału władzy, z ugruntowanymi instytucjami demokratycznymi sa źródłem narastajacego sprzeciwu społecznego przeciwko tej instytucji. Ominięcie instrumentów wewnętrznej kontroli działań państwa uzasadnione jest o tyle, o ile ta kontrola obciążona jest ryzykiem decyzji stronniczych. Jeżeli w odbiorze społecznym krajowy system sądowniczy działa prawidłowo, to arbitraż inwestycyjny coraz częściej bywa postrzegany jako instrument nieusprawiedliwione-

${ }^{33}$ Ch.N. Brower, L.A. Steven: Who Then Should Judge? Developing the International Rule of Law under NAFTA Chapter 11. "Chicago Journal of International Law” 2002, 2, s. 202; T. Schultz, C. Dupont: Investment Arbitration..., s. 1146.

${ }^{34}$ Zob. wypowiedź J. Pauls s ona: Enclaves of Justice (April 12, 2007). „University of Miami Legal Studies Research Paper" 2010, no. 29, https://ssrn.com/abstract=1707504.

${ }_{35}$ T. Schultz, C. Dupont: Investment Arbitration..., s. 1160-1161. Tak też można odczytać wypowiedź W. Sadowskiego: Protection..., s. 1035 i n. W tym ujęciu rule of law rozumiana jest jako działanie organów państwa z poszanowaniem zasad prawnych oraz realizowanie funkcji sądowniczych przez kompetentne i niezależne instytucje orzekające.

${ }^{36}$ Podkreślić jednak trzeba, że argument ten podważają krytycy arbitrażu inwestycyjnego, nie bez podstaw zarzucając obecnemu modelowi, że sam nie wprowadza mechanizmów instytucjonalnych zabezpieczających niezależność podmiotów orzekających. Zob. szerzej na ten temat G. Van Harten: Five Justifications for Investment Treaties: A Critical Discussion. „Trade, Law and Development” 2010, 2, s. 35 i n.

${ }^{37}$ Zob. badania przytoczone przez J. Bonnitcha: Assessing..., s. 5. 
go uprzywilejowania inwestora zagranicznego ${ }^{38}$. Arbitraż inwestycyjny wchodzi wówczas w kolizję z zasadami państwa praworządnego, stając się de facto instytucją naruszajaca zasady wolnego rynku przez przyznanie inwestorom zagranicznym ochrony procesowej niedostępnej ich konkurentom krajowym, działającym na tym samym rynku i w tym samym środowisku prawnym. Jak na ironię rozkwit arbitrażu inwestycyjnego nastąpił na początku XXI w., w czasie największych sukcesów demokracji liberalnej połaczonej z idea globalnej wolności gospodarczej ${ }^{39}$. W konsekwencji sprzeciw w stosunku do obecnego modelu nie ogranicza się już wyłącznie do państw rozwijających się, lecz pojawia się także w społeczeństwach państw rozwiniętych ${ }^{40}$.

Już obecnie wiele państw zareagowało na ten sprzeciw, zmieniając swoje podejście do rozwiązywania sporów inwestycyjnych. Można wskazać na trzy główne nurty obrazujące to zjawisko. Z jednej strony zidentyfikować można trend zmierzający do wykluczania w ogóle arbitrażu jako metody rozstrzygania sporów inwestycyjnych. W tym nurcie wyróżnić można kilka szczegółowych rozwiązań. Pierwszym rozwiązaniem jest rezygnacja z jakiejkolwiek zewnętrznej formuły ochrony inwestycji zagranicznych i powierzenie tej ochrony sądom krajowym. Rozwiązanie to bywa wynikiem bądź wypowiadania umów o ochronie inwestycji ${ }^{41}$, bądź

${ }^{38}$ Podobnie G. Van Harten, J. Kelsey, D. Schneiderman: Phase 2 of the UNCITRAL ISDS Review..., s. 7-8.

${ }^{39}$ Statystykę ilości spraw arbitrażowych oraz adresatów tych spraw przedstawiaja T. Schultz, C. Dupont: Investment Arbitration..., s. 1151 i n.

${ }^{40}$ Przykładem tego sprzeciwu mogą być protesty społeczne, które przetoczyły się przez państwa Unii Europejskiej w okresie negocjowania umowy o ochronie inwestycji między UE i USA oraz UE i Kanada, zob. np.: https://www.theguardian.com/commentisfree/2016/ may/05/protest-never-changes-anything-derailing-ttip-trade-agreement; https://www.reuters.com/article/us-eu-usa-ttip/tens-of-thousands-protest-in-europe-against-atlantic-freetrade-deals-idUSKCN11N0H6; https://www.bilaterals.org/?eastern-europe-against-ttiptro jan\&lang=en.

${ }^{41}$ W kierunku rozwiązania umów bilateralnych pomiędzy państwami Unii Europejskiej zmierza porozumienie 23 państw z dnia 5 maja 2020 r., https://eur-lex.europa.eu/le gal-content/EN/TXT/?uri=CELEX:22020A0529(01). Porozumienie jest efektem deklaracji z dnia 15 stycznia 2019 r., podjętej przez 22 państwa członkowskie Unii Europejskiej, o wypowiadaniu bilateralnych umów o ochronie inwestycji pomiędzy tymi państwami, https://www.iisd.org/itn/2019/04/23/achmea-judgement-fallout-22-eu-member-statesagree-to-terminate-intra-eu-bits/. Deklaracja ta jest z kolei pokłosiem orzeczenia TSUE w sprawie Slowakische Republik v Achmea BV, https://eur-lex.europa.eu/legal-content/ EN/TXT/?uri=CELEX\%3A62016CJ0284. Warto nadmienić, że wg raportu UNCTAD, 2017 r. był pierwszym rokiem, w którym państwa wypowiedziały więcej umów o ochronie inwestycji niż zawarły nowych umów. Tak C. Titi: Who's Afraid of Reform? Beware the Risk of Fragmentation. „American Journal of International Law Unbound” 2018, 112 , s. 232-236, doi:10.1017/aju.2018.71, s. 234, powołując World Investment Report z 2018 r., https://www.cambridge.org/core/journals/american-journal-of-international- 
zawierania nowych umów, w których nie przewidziano takiego sposobu ochrony inwestycji. Przykładami takich umów są porozumienie pomiędzy USA i Australia oraz porozumienie między Australią i Japonia ${ }^{42}$. Warto także wskazać na nowe ustawodawstwo Afryki Południowej (South Africa's Protection of Investment Act z 2015 r. ${ }^{43}$ ). Akt ten gwarantuje równorzędne traktowanie inwestorów krajowych i zagranicznych oraz przewiduje, że spory między inwestorem zagranicznym a państwem będą rozstrzygane $\mathrm{w}$ drodze mediacji lub przez sądy krajowe. Akt nie narusza ochrony przyznanej zagranicznym inwestorom przez wiążące Afrykę Południowa umowy o ochronie inwestycji, a jego działanie przewidziane jest na przyszłość.

Rozwiązaniem alternatywnym jest przeniesienie sporu inwestycyjnego do poziomu relacji między państwami. Tak też zmieniono w $2016 \mathrm{r}$. Finance and Investment Protocol, obowiązujący państwa tworzące Wspólnotę Rozwoju Afryki Południowej ${ }^{44}$. Także wspomniany wcześniej South Africa's Protection of Investment Act przewiduje możliwość przeniesienia sporu na poziom międzyrządowy, ale uzależnia uruchomienie tej drogi m.in. od wykorzystania przez inwestora krajowej ścieżki dochodzenia roszczeń. W kontekście rezygnacji z arbitrażu inwestycyjnego wspomnieć wypada również o Brazylii, która nigdy nie zdecydowała się na zawieranie umów o ochronie inwestycji przewidujących tę procedurę rozstrzygania sporu między inwestorem a państwem ${ }^{45}$. Podobnie Irlandia i Norwegia zachowały powściagliwość w kwestii podpisywania międzypaństwowych umów o ochronie inwestycji ${ }^{46}$.

law/article/whos-afraid-of-reform-beware-the-risk-of-fragmentation/5918DD3553CE666 F2B817823C2063339.

${ }^{42}$ T. Menon, G. Issac: Developing Country Opposition to an Investment Court: Could State-State Dispute Settlement be an Alternative? Kluwer Arbitration Blog, http:// arbitrationblog.kluwerarbitration.com/2018/02/17/developing-country-opposition-invest ment-court-state-state-dispute-settlement-alternative/.

${ }^{43}$ Act No. 22 of 2015, Protection of Investment Act, 2015, Republic of South Africa's Government Gazette, Vol. 606, 15 December 2015, No. 39514, http://www.thedtic.gov.za/ wp-content/uploads/Investment_Act_22of2015.pdf.

${ }^{44}$ K. Mohamadieh: The Future of Investor-State Dispute Settlement Deliberated at UNCITRAL: Unveiling a Dichotomy between Reforming and Consolidating the Current Regime. „Investment Policy Brief” 2019, 16, s. 7, https://www.southcentre.int/wp-con tent/uploads/2019/03/IPB16_The-Future-of-ISDS-Deliberated-at-UNCITRAL_EN.pdf.

${ }_{45}$ X. Carim: International Investment Agreements..., s. 57. W opracowanej brazylijskiej modelowej umowie inwestycyjnej (która od 2015 r. stanowi podstawę negocjacyjna tego kraju przy negocjowaniu porozumień handlowych z innymi państwami) również nie wprowadzono mechanizmu arbitrażowego, lecz przewidziano rozpatrywanie sporów inwestycyjnych na poziomie relacji międzypaństwowych. Zob. C. Titi: Who's Afraid of Reform?..., s. 235.

46 Ibidem, s. 234. 
W drugim nurcie pojawiają się rozwiązania utrzymujące model rozstrzygania sporów inwestycyjnych $\mathrm{w}$ ramach postępowania bezpośrednio między inwestorem i państwem, jednak w wersji zmodyfikowanej. Przykładem może być wprowadzanie w niektórych umowach lub umowach wzorcowych różnego rodzaju obowiązków w stosunku do inwestorów zagranicznych, które mogą się stać podstawą roszczeń wzajemnych państwa w stosunku do inwestora $\mathrm{w}$ arbitrażu bądź też zamknąc inwestorowi drogę do arbitrażu inwestycyjnego w przypadku naruszenia tych obowiązków ${ }^{47}$. W nurcie reformatorskim arbitrażu inwestycyjnego należy umieścić także propozycję stworzenia permanentnego, wielostronnego sądu inwestycyjnego (MIC), promowaną przez Unię Europejska ${ }^{48}$. W ocenie Unii Europejskiej stały sąd inwestycyjny ma stanowić antidotum na problemy, z którymi boryka się sądownictwo arbitrażowe ad hoc ${ }^{49}$. Stały sąd inwestycyjny (Investment Court System ICS) przewidziany w umowie UE z Kanada (CETA) i następnie powielany w kolejnych umowach handlowych zawieranych przez UE (np. z Wietnamem czy Singapurem) ma być instrumentem pośrednim $\mathrm{w}$ drodze do ustanowienia wielostronnego sądu inwestycyjnego ${ }^{50}$.

Trzeci nurt zmian, który prowadzi do ograniczenia zasięgu arbitrażu inwestycyjnego, polega na wprowadzaniu w niektórych umowach o ochronie inwestycji swego rodzaju „filtrów”, wyłączających zagadnienia szczególnie wrażliwe dla państwa z zakresu spraw podlegających jurysdykcji trybunału arbitrażowego ${ }^{51}$.

${ }^{47}$ K. Mohamadieh (The Future..., s. 8) wskazuje indyjską umowę modelową oraz umowę dwustronną Nigeria-Maroko jako przykład regulacji przewidujących dodatkowe obowiązki inwestora. Więcej na temat wymogów stawianych przez wzorcową umowę indyjska zob. C. Titi: Who's Afraid of Reform?..., s. 235. Z kolei w umowach zawieranych przez Turcję z Burundi, Mozambikiem i Ukrainą przewidziano, że ochrona inwestycji jest uzależniona od wkładu inwestora w zrównoważony rozwój i rozwój ekonomiczny kraju inwestycji.

${ }^{48}$ Można powątpiewać w to, czy proponowany instrument stanowić będzie nadal reformę arbitrażu inwestycyjnego w tym sensie, że taka instytucja nie powinna już być nazywana arbitrażem, cechuje ją bowiem wybieralność arbitrów przez strony. Niemniej jednak trzeba podkreślić tożsamość tej propozycji z obecnym modelem w tym sensie, że pozostawia on odpolitycznioną strukturę zewnętrzną w stosunku do państwa, która będzie rozpatrywać spory inwestycyjne.

${ }_{49}$ Zob. stanowisko z dnia 16 września 2015 r. ówczesnego komisarza ds. handlu UE C. Malmström: Proposing an Investment Court System, https://ec.europa.eu/commis sion/commissioners/2014-2019/malmstrom/blog/proposing-investment-court-system_en.

${ }^{50}$ L. Rönnelid: Research Report..., s. 7 i n.

${ }^{51}$ K. Mohamadieh (The Future..., s. 8) wskazuje mechanizm „filtrujacy” w umowie między Australią i Chinami, jak również propozycję wyłączenia spraw związanych z regulacjami antynikotynowymi, zgłoszone przez Australię najpierw na etapie Trans-Pacific partnership agreement i później w ramach Comprehensive and Progressive Agreement for Trans-Pacific Partnership. 


\section{Dyskusja w ramach prac Grupy Roboczej III UNCITRAL}

Narastająca i kompleksowa krytyka istniejącego modelu rozstrzygania sporów inwestycyjnych leży u podstaw rozpoczęcia prac nad reformą obecnego systemu w ramach prac UNCITRAL. Grupa Robocza III w pierwszym etapie prac zidentyfikowała podstawowe zarzuty podnoszone w stosunku do arbitrażu inwestycyjnego w raporcie z dnia 18 września 2017 r. $^{52}$ Problemy zostały podzielone na kilka grup. W pierwszej grupie problemów, w której ujęto aspekty procesowe oraz dotyczące wyniku postępowania, wymienia się: czas trwania postępowania oraz jego koszty, transparentność postępowania, standardy ochrony inwestycji (w kontekście ciagłości linii orzeczniczej i przewidywalności rezultatu) oraz ostateczność orzeczeń arbitrażowych (brak mechanizmu kontrolnego). W drugiej grupie znajdują się problemy dotyczące arbitrów (brak gwarancji niezawisłości i bezstronności, wąska grupa osób nominowanych jako arbitrzy, brak przejrzystości procesu nominacyjnego, problem „obrotowych drzwi” ${ }^{53}$, etyczne problemy wpływu finansowania arbitrażu przez osoby trzecie). W trzeciej grupie wymieniono problemy związane z ocena społeczną arbitrażu inwestycyjnego (asymetria postępowania dostępnego tylko inwestorom zagranicznym, pominięcie wewnętrznego krajowego systemu rozstrzygania sporów i szeroko ujęty brak legitymacji dla tego sposobu uprzywilejowania inwestorów zagranicznych w systemach demokratycznych) ${ }^{54}$. W toku dalszych prac Grupy Roboczej ustalono, że w ramach reformy systemu rozstrzygania sporów inwestycyjnych uwaga powinna zostać skupiona na następujaccych grupach zagadnień ${ }^{55}$ :

1. Brak ciągłości linii orzeczniczej, brak logicznej zgodności między różnymi orzeczeniami oraz ich poprawności. W tej grupie zagadnień należy skoncentrować się na następujących kwestiach:

${ }_{52}$ Possible reform of Investor-State dispute settlement (ISDS) Note by the Secretariat A/CN.9/WG.III/WP.142 [dalej: Note A/CN.9/WG.III/WP.142], https://undocs.org/ en/A/CN.9/WG.III/WP.142.

${ }^{53}$ Szerzej o problemie obrotowych drzwi M. Langford, D. Behn, R. Lie: The Revolving Door in International Investment Arbitration. „Journal of International Economic Law” 2017, 20, s. 301—331, https://academic.oup.com/jiel/article/20/2/301/3859188.

${ }^{54}$ Zob. także Note A/CN.9/WG.III/WP.142, s. 6-10.

${ }_{55} \mathrm{Na}$ podstawie dokumentu Possible reform of Investor-State dispute settlement (ISDS) Note by the Secretariat A/CN.9/WG.III/WP.166 z dnia 30 lipca 2019 r., s. 2-3 [dalej: Note A/CN.9/WG.III/WP.166], https://undocs.org/en/A/CN.9/WG.III/WP.166. Dokument ten uzupełnia stanowisko Working Group III, wyrażone wcześniej w dokumencie Possible reform of Investor-State dispute settlement (ISDS) Note by the Secretariat A/CN.9/WG.III/WP.149 z dnia 5 września 2018 r., https://undocs.org/en/A/CN.9/WG.III/ WP.149. 
a) nieusprawiedliwiona różnorodność procesu interpretacji postanowień traktatowych oraz zasad prawa międzynarodowego dokonywana przez trybunały orzekajace ${ }^{56}$;

b) brak ram prawnych dotyczących postępowań „zwielokrotnionych” (multiple proceedings); pod pojęciem postępowań „zwielokrotnionych" kryje się wiele różnych możliwych konfiguracji procesowych $^{57}$

c) kompletny brak lub niedoskonałość mechanizmów korygowania niespójnych bądź wadliwych orzeczeń w ramach istniejaccych traktatów ${ }^{58}$.

2. Problemy dotyczące arbitrów. W tej grupie zagadnień wymienia się:

a) braki w zakresie bezstronności i niezależności arbitrów ${ }^{59}$;

b) niedostatki w kwestii transparentności i efektywności mechanizmów ujawniania konfliktów interesów oraz w kwestii efektywności mechanizmów zmiany arbitra ${ }^{60}$;

c) homogeniczność społeczności arbitrażowej ${ }^{61}$;

d) wątpliwości w kwestii prawidłowości ukonstytuowania się trybunałów orzekających ${ }^{62}$.

3. Koszty i długość postępowań. W tej grupie problemów ujęto trzy zagadnienia szczegółowe:

a) koszty i długość postępowania oraz problem pozwów „lekkomyślnych" (frivolous claims) ${ }^{63}$

b) alokacja kosztów dokonywana przez trybunały orzekajace ${ }^{64}$;

c) zabezpieczenie kosztów postępowania ${ }^{65}$.

4. Finansowanie postępowania przez osoby trzecie. W tym zakresie podjęta jest próba zdefiniowania i uregulowania kwestii finansowania postępowania przez podmioty inne niż jego strony ${ }^{66}$.

5. Zagadnienia dodatkowe, takie jak:

a) inne metody rozstrzygania sporów inwestycyjnych niż arbitraż;

${ }^{56}$ Zob. Report of Working Group III (Investor-State Dispute Settlement Reform) on the work of its thirty-sixth session (Vienna, 29 October-2 November 2018) A/CN.9/964 z dnia 6 listopada 2018 r., § 39 i 40, s. 8 [dalej: Report A/CN.9/964], https://undocs.org/A/ CN.9/964.

${ }^{57}$ Co do szczegółów Report A/CN.9/964, §43, s. 8.

${ }_{58}$ Report A/CN.9/964, §54-63, s. 10 i 11.

${ }_{59}$ Report A/CN.9/964, §66-83, s. 11 i 13.

${ }^{60}$ Report A/CN.9/964, §84-90, s. 13 i 14.

${ }^{61}$ Report A/CN.9/964, §91-98, s. 14 i 15.

${ }^{62}$ Report A/CN.9/964, § 99-108, s. 15 i 16.

${ }^{63}$ Report A/CN.9/964, §110-123, s. $16-18$.

${ }^{64}$ Report A/CN.9/964, §124-127, s. 18.

${ }^{65}$ Report A/CN.9/964, §128-133, s. 19.

${ }_{66}$ Report A/CN.9/964, § $17-25$, s. 5 i 6. 
b) wymóg wykorzystania krajowych środków dochodzenia roszczeń przed skierowaniem sprawy do arbitrażu;

c) udział osób trzecich w postępowaniu;

d) skarga wzajemna w toku postępowania arbitrażowego;

e) problem „efektu mrożącego” w arbitrażu inwestycyjnym;

f) obliczanie odszkodowania ${ }^{67}$.

W toku prac Grupy Roboczej zwrócono uwagę na fakt, że arbitraż inwestycyjny generuje problemy nie tylko w aspekcie proceduralnym, lecz także materialnoprawnym. Uznano jednak, że mandat przyznany Grupie Roboczej przez UNCITRAL ogranicza się wyłącznie do szeroko ujętych zagadnień proceduralnych ${ }^{68}$.

Na posiedzeniu w Wiedniu, które odbyło się w dniach od 14 października do 18 października 2019 r., uzgodniono harmonogram prac na kolejne spotkania grupy oraz wstępnie przedyskutowano trzy problemy:

a) rozważano potrzebę stworzenia centrum doradczego w zakresie arbitrażu inwestycyjnego oraz potencjalny zakres zadań, jakie to centrum miałoby wykonywać ${ }^{69}$

b) rozważano, w jaki sposób i jak sprecyzować wymogi stawiane arbitrom i wiążące ich zasady postępowania; równocześnie zastanawiano się, w jaki sposób egzekwować ewentualne ustalenia w tym zakresie ${ }^{70}$; c) rozważano problem finansowania postępowań arbitrażowych przez osoby trzecie ${ }^{71}$.

Zwrócono jednocześnie uwagę na fakt, że wyniki reformy musza być zgodne z celami zrównoważonego rozwoju (Sustainable Development Goals - SDG) ${ }^{72}$, oraz że nie mogą utrudniać realizacji celów Porozumienia paryskiego ${ }^{73}$. Zalecono także, aby Sekretariat przeprowadził badania dotyczące metodologii obliczania odszkodowań w arbitrażu inwe-

${ }^{67}$ Report of Working Group III (Investor-State Dispute Settlement Reform) on the work of its thirty-seventh session (New York, 1-5 April 2019) z dnia 9 kwietnia $2019 \mathrm{r}$. A/CN.9/970, § 29—40, s. 6—8, https://undocs.org/A/CN.9/970.

${ }^{68}$ Note A/CN.9/WG.III/WP.166, § 7, s. 3 i 4 odwołuje się do mandatu wynikającego z Report A/72/17 §264, s. 46. Wątek zawężenia prac do zagadnień proceduralnych jest szerzej rozważany w dalszej części niniejszego opracowania.

${ }^{69}$ Report of Working Group III (Investor-State Dispute Settlement Reform) on the work of its thirty-eighth session (Vienna, 14-18 October 2019) A/CN.9/1004 z dnia 23 października 2019 r., §28—50, s. 8—11 [dalej: Report A/CN.9/1004], https://undocs. org/en/A/CN.9/1004.

${ }^{70}$ Report A/CN.9/1004, §51-78, s. 11-15.

${ }^{71}$ Report A/CN.9/1004, § 79-98, s. $15-18$.

${ }^{72}$ Więcej informacji na temat SDG zob. https://sustainabledevelopment.un.org/?me $\mathrm{nu}=1300$.

${ }^{73}$ Chodzi o porozumienie przyjęte podczas konferencji klimatycznej w Paryżu (COP21) w grudniu 2015 r. Zob. Report A/CN.9/1004, §99, s. 18. 
stycyjnym $^{74}$. W ramach prac dyskutowana jest również kwestia, w jaki sposób implementować wypracowane rozwiązania do istniejącej sieci porozumień inwestycyjnych ${ }^{75}$.

W dniach od 20 stycznia do 24 stycznia 2020 r. w Wiedniu miała miejsce 38. sesja Grupy Roboczej. Spotkanie to zaowocowało dyskusja dotyczącą wprowadzenia mechanizmu odwoławczego od orzeczeń trybunałów arbitrażowych. Do rozpatrywania takich skarg miałby zostać powołany stały organ. Szczególnie dyskusyjna była kwestia, jaki powinien być zakres weryfikacji dokonywanej przez organ odwoławczy, oraz jakie miałyby być konsekwencje takiej „apelacji”76. Przeprowadzono również wstępne rozważania dotyczące potencjalnych źródeł finansowania nowej instytucji odwoławczej77. Zastanawiano się też nad mechanizmami wyznaczania arbitrów. W tym zakresie dyskusja miała charakter bardzo ogólny. Trudno bowiem oczekiwać precyzyjnych ustaleń, gdy nie wiadomo, czy reforma zmierzać ma w kierunku powoływania stałych sędziów/ arbitrów, czy też dominować ma obecny mechanizm wyznaczania składów ad hoc ${ }^{78}$.

Prace nad reformą miały być kontynuowane podczas 39. sesji Grupy Roboczej, która miała się odbyć w Nowym Jorku, w dniach od 30 marca do 3 kwietnia 2020 r. W jej ramach miały być prowadzone rozmowy dotyczące struktury wypracowywanego rozwiązania wielostronnego i jego relacji do istniejaccej sieci umów o ochronie inwestycji ${ }^{79}$. Z uwagi na sytuację epidemiologiczna sesja ta została jednak bezterminowo przełożona.

Należy również wspomnieć, że dnia 1 maja 2020 r. ICSID i UNCITRAL przedstawiły projekt Kodeksu postępowania arbitrów w sporach inwestycyjnych, który stanowić ma próbę odpowiedzi na zarzuty dotyczące szeroko ujętego systemu powoływania arbitrów w arbitrażu inwestycyjnym (np. problemy konfliktu interesów czy kwestia tzw. double hatting, czyli występowania tych samych osób w różnych rolach — jako

${ }^{74}$ Report A/CN.9/1004, § 102, s. 19.

75 Report A/CN.9/1004, §101, s. 18.

${ }^{76}$ Report of Working Group III (Investor-State Dispute Settlement Reform) on the work of its resumed thirty-eight session (Vienna, 20-24 January 2020) A/CN.9/1004/ Add.1 z dnia 28 stycznia 2020 r., $§ 16$ i n., s. 5 i n. [dalej: Report A/CN.9/1004/Add.1], https://undocs.org/en/A/CN.9/1004/Add.1.

${ }_{77}$ A/CN.9/1004/Add.1, § 82-94, s. 14-15.

${ }_{78}$ A/CN.9/1004/Add.1, §95-133, s. 16-20. Problem ten pojawia się w rozważaniach F. Dias Simões: UNCITRAL Working Group III: Would an Investment Court De-politicize ISDS?, March 25, 2020, Kluwer Arbitration Blog, http://arbitrationblog. kluwerarbitration.com/2020/03/25/uncitral-working-group-iii-would-an-investmentcourt-de-politicize-isds/?doing_wp_cron=1592664439.3457798957824707031250.

${ }^{79}$ Possible reform of Investor-State dispute settlement (ISDS) Note by the Secretariat A/CN.9/WG.III/WP.194, https://undocs.org/en/A/CN.9/WG.III/WP.194. 
arbitrzy, pełnomocnicy stron bądź niezależni eksperci, co może wzbudzać uzasadnione watpliwości co do ich niezależności) ${ }^{80}$. Projekt ma stanowić punkt wyjścia do dalszych prac Grupy Roboczej.

\section{Potencjalne kierunki reformy arbitrażu inwestycyjnego}

Przytoczone sprawozdanie nie odzwierciedla złożoności prowadzonej dyskusji, a jej tło z pewnością wymagałoby przybliżenia. Nie jest to jednak możliwe $\mathrm{w}$ ramach niniejszego, ograniczonego z konieczności, opracowania. Trzeba jednocześnie podkreślić, że obecne kierunki dyskusji nie moga stanowić kierunkowskazów pozwalajacych przewidywać, jaki będzie finał prac Grupy. Dyskusja jest bardzo dynamiczna, a w toku prowadzonych rozmów zawsze podkreśla się, że nie przesądzaja one kształtu przyszłej reformy. Wynik prac Grupy Roboczej będzie w dużym stopniu uzależniony od tego, które z prezentowanych stanowisk uzyska z biegiem czasu przewagę. Można wskazać na trzy grupy ścierających się stanowisk $^{81}$, z tym że pamiętać trzeba, że linia demarkacyjna pomiędzy nimi nie jest ostra. Zwolenników pierwszego stanowiska nazwać można frakcją konserwatywna. W grupie tej panuje przekonanie, że arbitraż inwestycyjny nie wymaga większych modyfikacji, a drobne korekty możliwe są do wprowadzenia bądź w drodze wykładni istniejących umów, bądź $\mathrm{w}$ rezultacie niewielkich korekt legislacyjnych.

80 Zob. https://uncitral.un.org/en/codeofconduct. Krótkie omówienie propozycji przedstawiła Ch. Giorgetti: ICSID and UNCITRAL Publish the Anticipated Draft of the Code of Conduct for Adjudicators in Investor-State Dispute Settlement, May 2, 2020, Kluwer Arbitration Blog, http://arbitrationblog.kluwerarbitration.com/2020/05/02/icsid-and-uncit ralpublish-the-anticipated-draft-of-the-code-of-conduct-for-adjudicators-in-investorstatedispute-settlement/?doing_wp_cron=1592684708.7732639312744140625000.

81 A. Roberts (Incremental, Systematic, ad Paradigmatic Reform of Investor-State Arbitration. „American Journal of International Law” 2018, 112, s. 410) oraz C. Titi (Who's Afraid of Reform?..., s. 232) wskazuja na trzy kierunki proponowanych reform i na ich zwolenników, nazywając te kierunki odpowiednio: Incremental reform, Systematic reform oraz Paradigmatic reform, a ich zwolenników: Incrementalists, Systemic reformers oraz Paradigm shifters. We wcześniejszej wypowiedzi A. Roberts nazywała zwolenników tych kierunków odpowiednio: Loyalists, Reformists oraz Revolutionaries, wskazując jeszcze na czwartą grupę - tych, którzy na tym etapie pozostają niezdecydowani, którą z frakcji należy poprzeć. Zob. A. Roberts: The Shifting Landscape of Investor-State Arbitration: Loyalists, Reformists, Revolutionaries and Undecideds'. „International Economic Law and Policy Blog”, 15 June 2017, https://www.ejiltalk.org/theshifting-landscape-of-investor-state-arbitration-loyalists-reformists-revolutionaries-andundecideds/. 
Druga grupę nazwać można reformatorska. W jej ramach proponuje się dalej idącą reformę obecnego modelu, która ma zostać zrealizowana $\mathrm{w}$ efekcie wprowadzenia strukturalnych modyfikacji istniejacych ram postępowania. Najbardziej kompleksowa propozycję w tym zakresie przedstawiła Unia Europejska, postulująca wprowadzenie międzynarodowego stałego sądu inwestycyjnego, na wzór Europejskiego Trybunału Praw Człowieka.

Z kolei frakcja rewolucyjna bądź kwestionuje w ogóle użyteczność rozwiązywania sporów inwestycyjnych $\mathrm{w}$ ramach postępowania prowadzonego na poziomie międzynarodowym $\mathrm{z}$ udziałem państwa oraz inwestora, bądź też twierdzi, że system wymaga głębokiej, strukturalnej zmiany, nieograniczającej się jedynie do ram procesowych postępowania. Zwolennicy tego poglądu uważaja, że obecny system dotknięty jest fundamentalnymi wadami, które niemożliwe są do usunięcia w ramach zabiegów korygujących. Konsekwencją przyjęcia takiej perspektywy jest wniosek, że spory inwestycyjne powinny być rozstrzygane albo na poziomie relacji między rządami (stanowisko takie prezentuje Brazylia), albo że należy wprowadzić odpowiednie rozwiązania, umożliwiające dochodzenie roszczeń inwestorskich wyłącznie przed sądami kraju przyjmującego.

Nie można wykluczyć, że osiągnięcie jakiegokolwiek realnego konsensusu w przypadku tak rozbieżnych poglądów okaże się niemożliwe, a zaproponowane zmiany jedynie $\mathrm{w}$ drobnym stopniu przyczynia się do neutralizowania zidentyfikowanych problemów. Nie ulega bowiem wątpliwości, że w pierwszej fazie prac Grupy nakreślono kompleksowy i przekonujący obraz obecnego kryzysu ${ }^{82}$. Niestety, w pracach grupy ściera się wiele sprzecznych z sobą interesów i wizji, co oznacza, że realna jest obawa, iż nie uda się wypracować jednego modelu odpowiadającego wszystkim uczestnikom dyskusji. Prawdopodobnie właśnie ze względu na istniejące rozbieżności nie podjęto poważniejszych rozmów dotyczacych założeń strukturalnych planowanego modelu. I tak, gdy w trakcie 38. sesji miał pojawić się wysoce kontrowersyjny problem wielostronnego stałego sądu inwestycyjnego, dyskusja została ostatecznie zaaranżowana w ten sposób, że przedmiotem rozmów stały się zagadnienia bardziej szczegółowe $^{83}$. Taki sposób organizowania prac pozwala uniknąć kon-

${ }^{82}$ Podobnie G. Van Harten, J. Kelsey, D. Schneiderman: Phase 2 of the UNCITRAL ISDS Review..., s. 13.

${ }^{83}$ A. Nica (UNCITRAL Working Group III: One Step Closer to a Multilateral Investment Court?, March 24, 2020, Kluwer Arbitration Blog, http://arbitrationblog. kluwerarbitration.com/2020/03/24/uncitral-working-group-iii-one-step-closer-to-amultilateral-investment-court/?doing_wp_cron=1592656079.528554916381835937500) zwraca uwagę, że pierwotny harmonogram styczniowego posiedzenia Grupy Roboczej przewidywał, po raz pierwszy od rozpoczęcia prac Grupy, dyskusję na temat stałego sądu 
frontacji stanowisk dotyczacych pytań fundamentalnych i daje szansę na poszukiwanie kompromisów w ramach różnych zagadnień cząstkowych ${ }^{84}$. $\mathrm{Z}$ jednej strony takie zatomizowane podejście daje większe szanse na pewien postęp w pracach Grupy ${ }^{85}$. Z drugiej jednak strony zatomizowanie dyskusji i podzielenie jej na trudne do skoordynowania watki uniemożliwia zmierzenie się ze strukturalnymi problemami dotyczacymi istniejącego systemu. Pojawia się wówczas pytanie o sens osiagania drobnych kompromisów w sytuacji, gdy nie określono celu, do którego się zmierza ${ }^{86}$.

Mandat prac dla Grupy Roboczej III został określony przez UNCITRAL bardzo szeroko. Wydaje się jednak, że w toku prac doszło do jego zawężającej interpretacji. Jak już wspomniano, dominuje stanowisko, zgodnie z którym Grupa zajmuje się wyłącznie zagadnieniami proceduralnymi, jej mandat bowiem nie obejmuje zagadnień materialnoprawnych. Twierdzenie to budzi watpliwości. Z przebiegu prac UNCITRAL trudno jest wyprowadzić wniosek o takim ograniczeniu mandatu narzuconego Grupie Roboczej. Z jednej strony stwierdzono, że prace dotyczące rozwiąań materialnoprawnych nie sa tak pilne, jak prace dotyczące zagadnień proceduralnych ${ }^{87}$, oraz że Grupa powinna podjąc prace zmierzajace do udzielenia odpowiedzi na pytanie, czy i ewentualnie jakie zmiany konieczne sa w zakresie postępowania arbitrażowego w arbitrażu inwestycyjnym oraz w zakresie zasad etyki arbitrów ${ }^{88}$. Z drugiej jednak strony brzmienie samego mandatu nie zawiera żadnych ograniczeń i dotyczy zidentyfikowania problemów, ustalenia, czy reforma w ich kontekście jest wymagana, oraz zaproponowania potencjalnych rozwiązań. Co więcej, podkreśla się, że mandat ma bardzo szeroki zakres ${ }^{89}$. W pracach Grupy

arbitrażowego (MIC Multilateral Investment Court — wspomniany wcześniej projekt Unii Europejskiej). Zagadnienie to jest źródłem wielu rozbieżnych ocen. Temat nie został omówiony kompleksowo, lecz został podzielony na zagadnienia szczegółowe (wykonalność orzeczeń, finansowanie, wybór arbitrów), w których „rozmyła się” konieczność podejmowania decyzji w kwestiach bardziej kontrowersyjnych.

${ }^{84}$ Zob. komentarz A. Roberts, T.S. John: UNCITRAL and ISDS Reforms: What Makes Something Fly? (February 11, 2020), https://www.ejiltalk.org/uncitral-and-isdsreforms-what-makes-something-fly/.

${ }^{85}$ Ibidem.

${ }^{86}$ A. Roberts, T.S. John: UNCITRAL and ISDS Reform: Plausible Folk Theories, February 13, 2020, https://www.ejiltalk.org/uncitral-and-isds-reform-plausible-folk-the ories/. Autorki zwracają uwagę, że wątpliwość tę często podnoszą przedstawiciele świata nauki, organizacje społeczne czy niektóre państwa. Jednakże wiele państw, w szczególności tych, z których pochodzą duże korporacje eksportujące kapitał (potencjalni inwestorzy zagraniczni), zainteresowanych jest ograniczeniem pola dyskusji.

${ }^{87}$ Report A/72/17 § 257, s. 45 i 46.

88 Report A/72/17 $\$ 447$, s. 85.

89 Report A/72/17 §264, s. 46 i 47: „The Commission entrusted Working Group III with a broad mandate to work on the possible reform of investor-State dispute settle- 
Roboczej skupiono się jednak na zagadnieniach procesowych, choć rozumianych szeroko. Dominuje przekonanie, że za pomoca odpowiednio zmodyfikowanych instrumentów procesowych uda się rozwiązać także niektóre dylematy natury materialnoprawnej ${ }^{90}$. Jednocześnie takie zawężenie mandatu Grupy zmniejsza niebezpieczeństwo podjęcia zagadnień najbardziej spornych, a tym samym ryzyko niepowodzenia całego projektu. To właśnie zagadnienia materialnoprawne są nośnikiem najgłębszych wątpliwości dotyczących tej drogi rozstrzygania sporów między inwestorem i państwem. Trudno np. wyobrazić sobie, w jaki sposób, bez ingerencji w materialnoprawne podstawy rozstrzygania sporów inwestycyjnych, zażegnać niebezpieczeństwo efektu regulatory chill, gdy państwo powstrzymuje się od wprowadzania konkretnych rozwiąań legislacyjnych, nie mogac uprzednio przesądzić, jakie mogą być skutki ich ustanowienia z perspektywy roszczeń inwestycyjnych ${ }^{91}$. Tym bardziej trudno sobie wyobrazić, w jaki sposób w drodze wyłącznie proceduralnych modyfikacji obecnego modelu ma dojść do realizacji celów zrównoważonego rozwoju ${ }^{92}$. Obecnie trudno znaleźć jakieś wskazówki dotyczące tego zagadnienia, poza wspomnianą wcześniej ogólną deklaracją w ramach prac Grupy Roboczej. Nawet najbliższa całościowemu ujęciu problemu propozycja Unii Europejskiej, dotycząca prac nad stałym sądem inwestycyjnym, nie obej-

ment. In line with the UNCITRAL process, Working Group III would, in discharging that mandate, ensure that the deliberations, while benefiting from the widest possible breadth of available expertise from all stakeholders, would be Government-led,with high-level input from all Governments, consensus-based and fully transparent. The Working Group would proceed to: (a) first, identify and consider concerns regarding investor-State dispute settlement; (b) second, consider whether reform was desirable in the light of any identified concerns; and (c) third, if the Working Group were to conclude that reform was desirable, develop any relevant solutions to be recommended to the Commission. The Commission agreed that broad discretion should be left to the Working Group in discharging its mandate, and that any solutions devised would be designed taking into account the ongoing work of relevant international organizations and with a view to allowing each State the choice of whether and to what extent it wished to adopt the relevant solution(s)" [podkr. J.Z.].

${ }^{90}$ G. Van Harten, J. Kelsey, D. Schneiderman: Phase 2 of the UNCITRAL ISDS Review..., s. 2; zob. także A. Arcuri, F. Violi: Reforming ISDS..., s. 8.

${ }^{91}$ Zwracają na to uwagę: G. Van Harten, J. Kelsey, D. Schneiderman: Phase 2 of the UNCITRAL ISDS Review..., s. 10 i n. oraz A. Arcuri, F. Violi: Reforming ISDS..., s. 7.

${ }_{92}$ Tak również: G. Van Harten, J. Kelsey, D. Schneiderman: Phase 2 of the UNCITRAL ISDS Review..., s. 14; także N.J. Dia mond, K.A.N. Duggal: ISDS Reform and Advancing All „Generations” of Human Rights, June 17, 2020, Kluwer Arbitration Blog, http://arbitrationblog.kluwerarbitration.com/2020/06/17/isds-reform-and-advancingall-generations-of-human-rights/?doing_wp_cron=1592658056.1291019916534423828125 zwracają uwagę na brak odniesienia prac do celów zrównoważonego rozwoju, zaznaczajac, że w jakimś stopniu w pracach można znaleźć nawiązanie do 16. celu SDG. 
muje swoim zakresem wielu strukturalnych problemów odnoszących się chociażby do asymetrii całego systemu ukierunkowanego na potrzebę ochrony inwestora ${ }^{93}$. Wprawdzie mandat Grupy Roboczej nie wyklucza zajęcia się zagadnieniem skargi wzajemnej w arbitrażu inwestycyjnym ${ }^{94}$, jednak trudno sobie wyobrazić, że wątek ten może zostać rozstrzygnięty bez głębszej debaty, dotyczącej materialnoprawnych podstaw i zasad orzekania w arbitrażu inwestycyjnym.

Ostatecznie więc nie wydaje się możliwe rozwiązanie wszystkich zasygnalizowanych przez UNCITRAL trudności bez podjęcia dyskusji dotyczacej kwestii materialnoprawnych ${ }^{95}$ oraz bez ustalenia kompleksowych ram przyszłych rozwiązań. Dopiero w granicach tak zakreślonych ram można prowadzić prace szczegółowe. Wymagałoby to jednak odwrócenia obecnych zasad działania i ze względów wzmiankowanych wcześniej zwiększyło ryzyko porażki całego projektu. W tym zakresie zatem raczej nie należy oczekiwać przełomu.

Jak wcześniej wspomniano, finalny efekt prac zależeć będzie $\mathrm{w}$ dużym stopniu od tego, czy, a jeśli tak, to która z wymienionych powyżej trzech grup stanowisk uzyska przewagę. Każda grupa charakteryzuje się indywidualnymi cechami, które stanowią o jej mocnych oraz słabych stronach. Silną stroną frakcji konserwatywnej jest jej skład, w którym znaleźć można wiele państw wysoko rozwiniętych (eksporterów kapitału) oraz wielu uznanych praktyków arbitrażu, jak również główne instytucje arbitrażowe ${ }^{96}$. Wśród słabych stron tej grupy można wymienić dwie okoliczności. Po pierwsze, nie jest ona tak jednorodna, jak w przeszłości, i część państw wysoko rozwiniętych nie jest już zainteresowana utrzymaniem status quo. Na pierwszy plan wysuwają się tutaj Stany Zjednoczone, których stanowisko jest obecnie dosyć nieprzewidywalne, chyba najbliższe frakcji rewolucyjnej. Po drugie, nadmierny opór frakcji

${ }^{93}$ K. Mohamadieh: The Future..., s. 9.

94 A. De Luca: UNCITRAL Working Group III: Counterclaims in ISDS - Challenges and Prospects in Light of the UNCITRAL Reform Process, March 28, 2020, Kluwer Arbitration Blog, http://arbitrationblog.kluwerarbitration.com/2020/03/28/un citral-working-group-iii-counterclaims-in-isds-challenges-and-prospects-in-light-of-theuncitral-reform-process/?doing_wp_cron=1592665294.8821029663085937500000.

${ }^{95}$ K. Mohamadieh: The Future..., s. 10.

${ }_{96}$ A. Roberts: Incremental..., s. 418 i 419. Autorka zwraca uwage, że instytucje arbitrażowe cechuje możliwość przejścia z frakcji konserwatywnej do reformatorskiej. Instytucje te zainteresowane są bowiem utrzymaniem swoich wpływów i, jeśli nie będzie to możliwe w ramach obecnego modelu, będą dążyć do tego, aby wpisać się w model zmieniony. Przykładem może być tutaj przywołany wcześniej projekt kodeksu postępowania arbitrów w sporach inwestycyjnych, przygotowany przez ICSID i UNCITRAL. Dokument przygotowany jest w duchu bardzo ograniczonych modyfikacji stanu obecnego, jednak pozwala na wprowadzenie odważniejszych korekt, jeżeli w tym kierunku zmierzać będą ustalenia Grupy Roboczej. 
konserwatywnej w stosunku do propozycji głębszej reformy może doprowadzić do załamania się systemu i do uzyskania przewagi przez frakcję rewolucyjną (gdy państwa w większości zrezygnują z obecnie dominujacej drogi rozstrzygania sporów między inwestorem a państwem). Z tego też względu nie można wykluczyć z biegiem czasu przesuwania się zwolenników frakcji konserwatywnej w kierunku frakcji reformatorskiej ${ }^{97}$.

Propozycja reformatorska znalazła się chyba w najtrudniejszym położeniu, będąc w ogniu krytyki zarówno opcji konserwatywnej (zarzucającej reformatorom demontaż systemu), jak i opcji rewolucyjnej (twierdzącej, że nowe mechanizmy często stanowią jedynie próby zakamuflowania istniejacych problemów) ${ }^{98}$. Dodatkowy problem stanowi fakt, że frakcja reformatorska musi budować koalicję popierająca konkretne rozwiązanie, co jest trudniejsze niż zaproponowanie opcji, do których poszczególne państwa moga przystapić lub nie ${ }^{99}$. Głównym moderatorem dyskusji w ramach tej frakcji pozostaje Unia Europejska ze swoim projektem stałego sądu inwestycyjnego. Stanowisko tej frakcji może przeważyć w sytuacji, w której pojawi się zagrożenie dla całego systemu arbitrażu inwestycyjnego, co prawdopodobnie skutkowałoby zgodą na głębszą reformę wyrażoną przez obecnych konserwatystów. Jednocześnie reformatorzy mogą skorzystać na wsparciu frakcji rewolucyjnej w sytuacji, w której zwolennicy zmian radykalnych dojdą do wniosku, że przeważa stanowisko konserwatywne.

Państwa, które odrzucaja obecny system, znajduja się z jednej strony w dogodnej sytuacji (najczęściej bowiem mogą rozwiązywać lub wypowiadać wiążące je umowy i tą drogą uwalniać się z ram arbitrażu inwestycyjnego niezależnie od wyniku prac Grupy) $)^{100}$, jednak z drugiej strony uwolnienie się z ram obecnego systemu może być dla takich państw kłopotliwe, ze względu na zawarte najczęściej w istniejących umowach tzw. sunset clauses $^{101}$. Wielu zwolenników reform radykalnych uważa, że system nie musi być całkowicie odrzucony, jeśli zostanie kompleksowo zreformowany, a zmiany nie ograniczą się do wątków proceduralnych, lecz obejmą także zagadnienia materialnoprawne. Ta grupa może ostatecznie wesprzeć frakcję reformatorską, jeśli okaże się, że tak radykalne zmiany nie są na tym etapie możliwe ${ }^{102}$.

97 Ibidem, s. 419.

98 Ibidem, s. 420.

${ }^{99}$ Ibidem, s. 419.

${ }^{100}$ Ibidem, s. 421.

101 Są to klauzule pozwalające dojść do skutku postanowieniom umów inwestycyjnych przez określony czas po ich wypowiedzeniu (najczęściej jest to 10 lub 20 lat). Zob. np. G. Zarra: The Issue of Incoherence in Investment Arbitration: Is There Need for a Systemic Reform? „Chinese Journal of International Law” 2018, 17, s. 181-182.

102 A. Roberts: Incremental..., s. 422. 


\section{Podsumowanie}

Przy obecnym rozproszeniu stanowisk najbardziej prawdopodobny scenariusz jest taki, że prace zmierzać będą w kierunku wypracowania wachlarza różnych rozwiązań proceduralnych, które na zasadzie dobrowolności będą mogły zostać przyjęte przez poszczególne państwa. Takie elastyczne ramy powodują, że państwa będą zainteresowane w wypracowaniu owego wachlarza rozwiązań, wśród których będą mogły poszukiwać opcji najbardziej odpowiadającej ich potrzebom ${ }^{103}$. Nie można jednak pominać, że taka pogłębiona defragmentacja obecnego systemu może stanowić dla niego raczej dodatkowe zagrożenie niż być lekarstwem na istniejacce problemy ${ }^{104}$. Z jednej strony brak ujednoliconych rozwiązań systemowych można potraktować jako przejaw różnorodności, która pozwoli dopasować istniejace instrumenty do realiów lokalnych ${ }^{105}$. Z drugiej jednak strony świat stoi obecnie przed wyzwaniami, które wymagają raczej jednolitego współdziałania państw i kształtowania jednolitej, kompromisowej polityki międzynarodowej niż dalszego jej rozpraszania. Osiągnięcie celów zrównoważonego rozwoju nie stanowi w tej chwili wyboru poszczególnych państw, lecz jest raczej wspólnym wyzwaniem dla ludzkości, o ile dąży ona do uchronienia cywilizacji przed egzystencjalnym kryzysem. Konieczność kształtowania polityki inwestycyjnej przez pryzmat poszanowania praw człowieka i ochrony klimatu nie jest jedynie wyzwaniem moralnym, lecz przejawem instynktu samozachowawczego. Jeśli na ochronę inwestycji nie spojrzy się kompleksowo, to tym samym utraci się sposobność przekształcenia arbitrażu inwestycyjnego $\mathrm{z}$ instrumentu chroniącego głównie interesy dużych inwestorów $\mathrm{w}$ instrument chroniący także społeczności lokalne oraz mający w centrum uwagi społeczne, środowiskowe i klimatyczne oddziaływania inwestycji. Światowa polityka inwestycyjna musi faktycznie, a nie tylko werbalnie wesprzeć realizację celów zrównoważonego rozwoju ${ }^{106}$. Niestety, nie wydaje się realne, aby w toku prac reformatorskich nad arbitrażem inwe-

${ }^{103}$ A. Roberts, T.S. John (UNCITRAL and ISDS Reforms: What Makes Something Fly?...) twierdza: „If states know that they will ultimately have a choice on which options to join, they may feel more comfortable spending their time developing options so they will have a good menu of reforms from which to choose later. Although this approach takes time, it is much more inclusive than having one or more delegation provide a fully developed prototype and it is likely to ensure greater buy in to the process overall".

${ }^{104}$ C. Titi: Who's Afraid of Reform?..., s. 236.

${ }_{105}$ Ciekawą analizę dostępnych opcji, wraz z oceną ich silnych i mocnych stron, przedstawiaja S. Puig, G. Shaffer: Imperfect Alternatives..., s. 383 i n.

106 Zwracają uwage na ten problem A. Arcuri, F. Violi: Reforming ISDS..., s. 14. 
stycyjnym powyższy postulat mógł zostać zrealizowany. Z jednej strony kryzys arbitrażu inwestycyjnego może być wykorzystany przez państwa, które zmierzają obecnie w kierunku polityki izolacjonistycznej i nacjonalistycznej, i w ramach realizowanego skrętu ideologicznego zainteresowane są mniej lub bardziej radykalna ingerencją w politykę inwestycyjną. Z drugiej strony istnieje silna grupa podmiotów zainteresowanych utrzymaniem status quo, które opierają swoją działalność profesjonalna na strukturach obecnego modelu. Podmioty te dążą do zneutralizowania tendencji reformatorskich, często pod hasłami łagodnej adaptacji obecnego modelu do nowych wyzwań. W takich realiach naiwne jest raczej przeświadczenie, że może dojść do przyjęcia rozwiązań uwzględniających rzeczywiste wyzwania, przed którymi stoi obecnie świat.

\section{Bibliografia}

Arcuri A., Violi F.: Reforming ISDS: Changing (Almost) Everything, So That Everything Stays the Same?, September 26, 2019, https://ssrn.com/abs tract $=3459961$.

Behn D., Laudal Berge T., Langford M.: Poor States or Poor Governance? Explaining Outcomes in Investment Treaty Arbitration. „Northwestern Journal of International Law \& Business" 2018, 38.

Bonnitcha J.: Assessing the Impacts of Investment Treaties: Overview of the evidence. International Insttitute for Sustainable Development (IISD) Report, September 2017, https:/www.iisd.org/sites/default/files/publications/ assessing-impacts-investment-treaties.pdf.

Brower Ch.N., Steven L.A.: Who Then Should Judge? Developing the International Rule of Law under NAFTA. Chapter 11. „Chicago Journal of International Law" 2002, 2.

Carim X.: International Investment Agreements and Africa's Structural Transformation: A Perspective from South Africa. In: Rethinking Bilateral Investment Treaties: Critical Issues and Policy Choices. Eds. K. Singh, B. Ilge. Amsterdam-New Delphi2016, https://www.somo.nl/wp-content/uplo ads/2016/03/Rethinking-bilateral-investment-treaties.pdf.

Cosmos J.: Legitimacy Crisis in Investor - State International Arbitration System: A Critique on the Suggested Solutions \& the Proposal on the Way Forward. „International Journal of Scientific and Research Publications” 2014, 4 .

Czech K.: Dowody i postepowanie dowodowe w międzynarodowym arbitrażu handlowym oraz inwestycyjnym. Zagadnienia wybrane. Warszawa 2017.

De Luca A.: UNCITRAL Working Group III: Counterclaims in ISDS - Challenges and Prospects in Light of the UNCITRAL Reform Process, March 
28, 2020, Kluwer Arbitration Blog, http://arbitrationblog.kluwerarbitration. com/2020/03/28/uncitral-working-group-iii-counterclaims-in-isds-chal lenges-and-prospects-in-light-of-the-uncitral-reform-process/?doing_wp_cro $\mathrm{n}=1592665294.8821029663085937500000$.

Diamond N.J., Duggal K.A.N.: ISDS Reform and Advancing All „Generations" of Human Rights, June 17, 2020, Kluwer Arbitration Blog, http://ar bitrationblog.kluwerarbitration.com/2020/06/17/isds-reform-and-advancingall-generations-of-human-rights/?doing_wp_cron=1592658056.12910199165 34423828125 .

Dias Simões F.: UNCITRAL Working Group III: Would an Investment Court De-politicize ISDS?, March 25, 2020, Kluwer Arbitration Blog, http:// arbitrationblog.kluwerarbitration.com/2020/03/25/uncitral-working-groupiii-would-an-investment-court-de-politicize-isds/?doing_wp_cron=15926644 39.3457798957824707031250.

Djajić S.: Searching for purpose: Critical assessment of teleological interpretation of treaties in investment arbitration, International Review of Law, Issue 3 - Special issue of International Investment Treaties, 2016, https://jour nals.qu.edu.qa/index.php/IRL/article/view/1217/658.

Giorgetti Ch.: ICSID and UNCITRAL Publish the Anticipated Draft of the Code of Conduct for Adjudicators in Investor-State Dispute Settlement, May 2, 2020, Kluwer Arbitration Blog, http://arbitrationblog.kluwerarbitration. com/2020/05/02/icsid-and-uncitral-publish-the-anticipated-draft-of-the-co de-of-conduct-for-adjudicators-in-investor-state-dispute-settlement/?doing wp_cron=1592684708.7732639312744140625000.

Jeżewski M.: Międzynarodowe prawo inwestycyjne. Warszawa 2019.

Kałduński M.: Ochrona uzasadnionych oczekiwań w międzynarodowym prawie inwestycyjnym. Torun 2019.

Kułaga Ł.: Międzynarodowa ochrona środowiska a swoboda handlu. W: Swoboda handlu międzynarodowego $w$ prawie międzynarodowym. Red. C. Mik, M. Jeżewski. Warszawa 2014.

Kułaga Ł.: Międzynarodowy arbitraż inwestycyjny z perspektywy zasady rzadów prawa. W: Arbitraż w prawie międzynarodowym. Red. C. Mik. Warszawa, C.H. Beck, 2014.

Kułaga Ł.: Ochrona praw człowieka $w$ międzynarodowym arbitrażu inwestycyjnym. „Forum Prawnicze” 2014, nr 1.

Kułaga Ł.: Prawo państwa do regulacji a międzynarodowe prawo inwestycyjne: $w$ kierunku zmiany paradygmatu. „Problemy Współczesnego Prawa Międzynarodowego, Europejskiego i Porównawczego” 2019, T. 17.

Kułaga Ł.: W kierunku zmiany paradygmatu międzynarodowych porozumień inwestycyjnych. „Forum Prawnicze” 2016, nr 5.

Langford M., Behn D., Létourneau-Tremblay L.: Empirical perspectives on investment arbitration: What do we know? Does it matter? ISDS Academic Forum Working Group 7 Paper, https://www.cids.ch/images/Documents/ Academic-Forum/7_Empirical_perspectives_-_WG7.pdf. 
Langford M., Behn D., Lie R.: The Revolving Door in International Investment Arbitration. „Journal of International Economic Law” 2017, 20, https:// academic.oup.com/jiel/article/20/2/301/3859188.

Menon T., Issac G.: Developing Country Opposition to an Investment Court: Could State-State Dispute Settlement be an Alternative? Kluwer Arbitration Blog, http://arbitrationblog.kluwerarbitration.com/2018/02/17/developing-co untry-opposition-investment-court-state-state-dispute-settlement-alterna tive/.

Mohamadieh K.: The Future of Investor-State Dispute Settlement Deliberated at UNCITRAL: Unveiling a Dichotomy between Reforming and Consolidating the Current Regime, „Investment Policy Brief” 2019, 16, https:// www.southcentre.int/wp-content/uploads/2019/03/IPB16_The-Future-ofISDS-Deliberated-at-UNCITRAL_EN.pdf.

Monebhurrun N.: Is investment arbitration an appropriate venue for environmental issues? A Latin American perspective, Revista De Direito Inernacional. „Brazilian Journal of International Law” 2013, 10.

Nica A.: UNCITRAL Working Group III: One Step Closer to a Multilateral Investment Court?, March 24, 2020, Kluwer Arbitration Blog, http://arbitra tionblog.kluwerarbitration.com/2020/03/24/uncitral-working-group-iii-onestep-closer-to-a-multilateral-investment-court/?doing_wp_cron=1592656079 .5285549163818359375000 .

Puig S., Shaffer G.: Imperfect Alternatives: Institutional Choice and the Reform of Investment Law. „The American Journal of International Law” 2018, 112.

Pyka M.: Pojęcie inwestycji $w$ międzynarodowym arbitrażu inwestycyjnym. Warszawa 2018.

Roberts A.: Incremental, Systematic, ad Paradigmatic Reform of Investor-State Arbitration. „American Journal of International Law” 2018, 112.

Roberts A.: The Shifting Landscape of Investor-State Arbitration: Loyalists, Reformists, Revolutionaries and Undecideds. „International Economic Law and Policy Blog", 15 June 2017, https://www.ejiltalk.org/the-shifting-lands cape-of-investor-state-arbitration-loyalists-reformists-revolutionaries-andundecideds/.

Roberts A., John T.S.: UNCITRAL and ISDS Reform: Plausible Folk Theories, February 13, 2020, https://www.ejiltalk.org/uncitral-and-isds-reform-plausible-folk-theories/.

Roberts A., John T.S.: UNCITRAL and ISDS Reforms: What Makes Something Fly?, February 11, 2020, https://www.ejiltalk.org/uncitral-and-isdsreforms-what-makes-something-fly/.

Rönnelid L.: Research Report: An Evaluation of the Proposed Multilateral Investment Court System, An independent report commissioned by the European United Left/Nordic Green Left (GUE/NGL) in the European Parliament 2018, https://www.guengl.eu/content/uploads/2019/03/MIC_vRET_web_FI NAL2.pdf. 
Sadowski W.: Protection of the Rule of Law in the European Union Through Investment Treaty Arbitration: Is Judicial Monopolism the Right Response to Illiberal Tendencies in Europe? „Common Market Law Review” 2018, 55.

Schultz T., Dupont C.: Investment Arbitration: Promoting the Rule of Law Or Over-Empovering Investors? A Quantitative Empirical Study. „The European Journal of International Law" 2015, vol. 25, no. 4, http://www.ejil.org/ pdfs/25/4/2551.pdf.

Titi C.: Who's Afraid of Reform? Beware the Risk of Fragmentation. „American Journal of International Law Unbound" 2018, 112, https://www.cambridge. org/core/journals/american-journal-of-international-law/article/whos-afraidof-reform-beware-the-risk-of-fragmentation/5918DD3553CE666F2B81782 3C2063339.

Van Harten G.: Five Justifications for Investment Treaties: A Critical Discussion. „Trade, Law and Development” 2010, 2.

Van Harten G.: Investment Treaty Arbitration and Public Law. Oxford University Press 2007.

Van Harten G.: Investment Treaty Arbitration. Procedural Fairness, and the Rule of Law. In: Investment Law and Comparative Public Law. Ed. S.W. Schill. Oxford 2010.

Van Harten G., Kelsey J., Schneiderman D.: Phase 2 of the UNCITRAL ISDS Review: Why 'Other Matters' Really Matter (2019). All Papers 328, https://digitalcommons.osgoode.yorku.ca/cgi/viewcontent.cgi?article$=1335 \&$ context $=$ all_papers.

Van Harten G., Malysheuski P.: Who Has Benefited Financially from Investment Treaty Arbitration? An Evaluation of the Size and Wealth of Claimants, January 11, 2016. „Osgoode Legal Studies Research Paper” 2016, no. 14, https://ssrn.com/abstract=2713876 lub http://dx.doi.org/10.2139/ ssrn.2713876.

Van Harten G., Porterfield M.C., Gallagher K.P.: Investment Provisions in Trade and Investment Treaties: The Need for Reform, A Global Economic Governance Initiative Policy Brief, https://www.bu.edu/pardeeschool/ files/2014/12/Investor-State-Disputes-Policy-Brief.pdf.

Zarr a G.: The Issue of Incoherence in Investment Arbitration: Is There Need for a Systemic Reform? „Chinese Journal of International Law” 2018, 17.

\section{Dokumenty UNCITRAL}

Possible reform of inwestor-State dispute settlement (ISDS) Note by the Secretariat A/CN.9/WG.III/WP.142, https://undocs.org/en/A/CN.9/WG.III/WP.142.

Possible reform of Investor-State dispute settlement (ISDS) Note by the Secretariat A/CN.9/WG.III/WP.149, https://undocs.org/en/A/CN.9/WG.III/WP.149.

Possible reform of Investor-State dispute settlement (ISDS) Note by the Secretariat A/CN.9/WG.III/WP.166, https://undocs.org/en/A/CN.9/WG.III/ WP.166. 
Possible reform of Investor-State dispute settlement (ISDS) Note by the Secretariat A/CN.9/WG.III/WP.194, https://undocs.org/en/A/CN.9/WG.III/ WP.194.

Report of Working Group III (Investor-State Dispute Settlement Reform) on the work of its thirty-sixth session (Vienna, 29 October - 2 November 2018) A/CN.9/964, https://undocs.org/A/CN.9/964.

Report of Working Group III (Investor-State Dispute Settlement Reform) on the work of its thirty-seventh session (New York, 1-5 April 2019) A/CN.9/970, https://undocs.org/A/CN.9/970.

Report of Working Group III (Investor-State Dispute Settlement Reform) on the work of its thirty-eighth session (Vienna, 14-18 October 2019) A/CN. 9/1004, https://undocs.org/en/A/CN.9/1004.

Report of Working Group III (Investor-State Dispute Settlement Reform) on the work of its resumed thirty-eight session (Vienna, 20-24 January 2020) A/CN.9/1004/Add.1, https://undocs.org/en/A/CN.9/1004/Add.1. 